\title{
THE CO-OPTATION OF SENSIBILITY AND THE SUBVERSION OF BEAUTY
}

\section{A B S T R A C T}

The aesthetic analysis of everyday life has developed an important body of work whose significance extends beyond the academy. Because of its ubiquity in experience, aesthetic sensibility has many manifestations, both overt and concealed. This paper examines some largely hidden ways in which taste and aesthetic judgment, which are manifested in sense experience, have been subtly appropriated and exploited. I identify and describe such procedures as the cooptation (or appropriation) of aesthetic sensibility, a phenomenon that has consequences damaging to health, to society, and to environment. These practices are a form of negative aesthetics that distorts and manipulates sensible experience in the interest of mass marketing and political control. Such practices have great ethical significance and carry social and political implications that suggest another role for aesthetics, a critical one: aesthetics as an instrument of emancipation in social analysis and political criticism. 
In due time, the theory of aesthetics will have to account not only for the delight in Kantian beauty and the sublime, but for the phenomena like aesthetic violence and the aestheticization of violence, of aesthetic abuse and intrusion, the blunting of sensibility, its perversion, and its poisoning. ${ }^{1}$

As a philosopher, I think of emancipation in cognitive terms. It is intellectual enlightenment of the sort that Francis Bacon attempted to instate by exposing 'the idols and false notions which are now in possession of the human understanding, and have taken deep root therein...'.2 It is Spinoza's (16321677) ideal of a mind, freed from the blinding force of the emotions and guided by adequate ideas, a mind that achieves true equanimity. ${ }^{3}$ That we still struggle for emancipation is a humbling fact. At the same time, in our day the obstacles to emancipation are not only ignorance of natural causes or human psychology that clouds the understanding. Our need for emancipation continues to come from inadequate ideas and false systems of philosophy (Bacon's 'Idols of the Theatre') from sources undreamed of in the seventeenth century or, indeed, in some cases, unknown before the immediate present. It is with emancipation from these last sources that I am concerned here.

Since the material of the philosophic enterprise is ideas, it is in that realm that, as philosophers, we can hope to contribute. From a pragmatic orientation, the contribution should be ideas that make a difference in behavior, unlike most philosophical discourse. And in keeping with the social context of behavior, such ideas should contribute to behavior that works toward emancipation in the social process. A thoughtful European philosopher once commented on 'the difference between a man who is led solely by feeling or opinion, and a man who is led by reason. The former,' he wrote, 'whether he will it or not, performs actions of which he is utterly ignorant; the latter is his own master and only performs such actions that he knows are of primary importance in life and therefore chiefly desires [them]. Therefore I call the former a slave, and the latter a free man..."4

Guided by Spinoza's idea of freedom, I would like to approach the subject of emancipation, presumably a moral and political concern, from the unlikely direction of aesthetics. The observation in my recent book, Sensibility and Sense: The Aesthetic Transformation of the Human World, serves as the frame of my comments: 
Aesthetic values are no longer confined to the museum and the scenic drive where they are honored but kept isolated and innocuous. They have become increasingly prominent in conflicts with values in morality, religion, economics, environment, and social life. ${ }^{5}$

Over the past half century, philosophical aesthetics has broadened its scope beyond an interest in beauty in the arts and in nature. Following the lead of the arts themselves, the field of aesthetics has spread outward to encompass the environment in all its forms, not only the scenic landscape but the devastated one, as well, and not only the natural environment but also the urban environment. ${ }^{6}$ Over the past half century a considerable body of literature on environmental aesthetics has grown out of these concerns. Aesthetic inquiry has also been directed at humans: personal experiences and relationships, the human body itself, social behavior, and political manifestations are being studied and assessed from an aesthetic vantage. Most recently, over the past decade or so, ordinary objects and experiences have preoccupied a growing number of scholars, and the aesthetics of everyday life has become a center of attention.

This work has had a profound effect on the field of aesthetics. Not only does aesthetic inquiry now embrace the objects, activities, and experiences of human life without constraint but it necessarily implicates other areas of philosophy. As aesthetic inquiry embraces social domains, ethical and even metaphysical concerns cannot be ignored. When eyes sensitive to beauty in art and nature encounter the objects and activities of ordinary life, they see not only their hidden charms ${ }^{7}$ but also their failings. ${ }^{8}$ Aesthetics then becomes a moral instrument and even a political factor in developing new thought in social and political aesthetics. ${ }^{9}$

The aesthetics of everyday life offers a fresh perspective on the world of ordinary experience, revealing facets that have long gone unremarked. These experiences may not be spectacular and may even be routine. Aesthetic value is discovered in common objects, conditions, and situations, ranging from the houses, landscaping, and trees encountered during a walk in one's own neighborhood, to basking in the spring sunshine; from tossing a ball back and forth and even, one scholar has suggested, to finding a certain aesthetic satisfaction in hanging laundry. ${ }^{10}$ As Yuriko Saito has noted, "We are yet to develop an aesthetic discourse regarding artifacts such as utensils, furniture, and other objects with which we interact in everyday environment and activities that we undertake with them, such as cleaning, cooking, and socializing with others." ${ }^{11}$ All these offer occasions of delighting in the sensible experience of an ordinary situation and the sheer sensory pleasure of being alive. ${ }^{12}$ 
We are not sufficiently aware that the origins of aesthetic value lie in sense experience. That this is the case is shown not only in the etymology of the term 'aesthetics' (from the Greek aisthēsis, perception by the senses) but also in the dependence of aesthetic appreciation on the sensory content of our encounter with a work of art or a natural landscape. This encounter centers on perceptual experience: acuteness in viewing, listening, touching - the full somatic engagement with the rich world of sensible experience in which we are inextricably embedded. ${ }^{13}$

For such reasons, etymological and experiential as well as historical, I think of aesthetics as the theory of sensibility. Whether sensibility is concerned with the arts, with nature, or with perceptual experience as such, aesthetic appreciation centers on a sensitivity to perceptual qualities as they are directly experienced, to their qualitative sensoriness. We experience the pleasures of sensibility in the arts and in natural beauty, but such sensory gratification also occurs in the activity of savoring the flavors, textures, and aromas of a well-prepared dinner. It is part of the pleasure we take in the cut, color, and fabric of new clothes. It is the delight we have in the intense, low-angled sunlight that causes fall foliage to glow or the snowy landscape to gleam. It occurs, too, in confronting the color abstraction of a Rothko or Frankenthaler painting. Such experience lies at the center of the delight, the pleasure, the emotional feelings associated with beauty wherever we encounter it. Clearly, sensibility is not the whole of art or of beauty but it lies at its core. This understanding of aesthetic value differs from how it is commonly understood, associated as it is almost entirely with the fine arts and with scenic beauty in nature. Identifying aesthetics with sensibility captures the central force in the value we take in the activity of aesthetic appreciation, whether of the arts, of nature, or of ordinary life.

\section{I}

Because of its ubiquity, sensibility has many manifestations, both overt and concealed. I want to examine here some largely hidden practices by which aesthetic sensibility has been subtly appropriated and exploited. These practices have resulted in what I call 'the co-optation of sensibility.' Their damaging consequences to health, society, and environment are incalculable. Let me explain.

As one cannot help being aware, the developed world has fostered an industrialcommercial culture obsessed with profitability. From schools to public agencies, no institution is immune to the business imperative of reducing costs and 
increasing profits. Service institutions, whose raison d'être is to meet people's needs and promote the transmission of culture, are particularly vulnerable, since the high labor costs of providing services is a major expense and directly impedes the maximization of profit. This model has taken a firmer and firmer hold on schools and universities, on health care, and public services of every kind. All have been subsumed under the model of profit-making enterprises.

It doesn't take much insight to recognize this pervasive pattern. Education has been turned into a lucrative business whose degrees are sometimes offered and acquired with minimal requirements. Even our public schools have become outlets for the marketing of junk food through vending machines in the hallways and commercialized school lunches, part of a pervasive and insidious pattern of exploiting children as consumers. Furthermore, who owns the air? Who owns the lakes and streams? Our environmental commons has been captured by industry, leading to air and water pollution as a by-product of industrial processes. The pattern is bold and blatant and it is pernicious, for what suffers is the public and its need for conditions and services that make living in community healthful and fulfilling, rather than a situation that is oppressive, tense, exhausting, and exploitative.

We can see this pattern most clearly in the privatization and appropriation of our environmental and technological commons, from the visual pollution of billboards and power lines infesting scenic landscapes to the industrial pollution of our rivers and the very air we breathe. ${ }^{14}$ Moreover, everyoneis presumed to have a right to the benefits of innovative technological resources, whether electronic devices or flights to luxury vacations in distant places. Sometimes their pursuit is justified as a panacea for real or presumed ills, but often it is merely self-indulgence. Everything has a price and everyone expects to be able to afford it. ${ }^{15}$ Actually, the taste for the most up-to-date is a constructed taste, a cultivated desire that is ideologically driven through intensive advertising in the service of the profit motive. Coupled with this is the pervasiveness of the commercial pressure that not only impinges on us in public places but insinuates itself onto the very clothes we wear in the form of commercial logos on their front and bald advertisements covering their back, turning the purchaser into a walking billboard.

Profit is, of course, the principal motive of most business enterprises, and I am not condemning it as such. What can be contested is whether the business model can serve as a universal template for the social order. Actually, some individuals in the business community are concerned about business ethics, and 
this area of applied ethics has received attention in recent years from scholars. ${ }^{16}$ What is at issue, however, is whether that model justifies manipulative and exploitative practices and, more to the point of this essay, the practices widely followed that I shall describe as the co-optation of sensibility.

For there is a less obvious and exploitative practice in our profit-obsessed culture that is almost completely hidden. It is a subtle form of subverting the genuinely human capacity for fulfillment that lies at the heart of the aesthetic. For there is, I believe, what some writers have called an 'aesthetic need.' ${ }^{17}$ We commonly seek out situations that reward our desire for the pleasures of sensible experience. We visit gardens, parks, and art museums; we engage in a wide range of non-competitive outdoor experiences, such as swimming, hiking, and camping; we take delight in colors, clothes, cuisine, a new car; we attend concerts, festivals, and rituals; we stroll through an historic district. All these have diverse appeal but they share the intense gratification we get from sensible experience and the uplift that comes from being taken out of ourselves, expanding our very sense of being alive by engaging in such experiences. The impulse to engage in aesthetic experience is, I think, widely shared though mostly undeveloped. It is important that we recognize it. It is important that we cultivate it.

But in our contemporary intensely commercial culture, no pure impulse is allowed to remain unsullied if it can be made to serve profitable ends, and our aesthetic need can be exploited all too easily. When 'the public' is transformed into 'the consumer,' everyone is vulnerable. Not only is our desire for sensible experience taken over; our very sensibility is corrupted by isolating and exaggerating it. Our impulse for beauty, for delight, for sensory satisfaction is widely appropriated in the service of maximizing profit at the expense of the pleasure and fulfillment of individual people and of society as a whole. This is the co-optation of sensibility. The word 'co-optation' is not in common use but it has special significance in social and political critique. ${ }^{18}$ It means 'secretly appropriating,' taking something over to serve one's own interests. In this aesthetic case, the appropriation is hidden so that the 'victim' is entirely unaware of what is being perpetrated.

The co-optation of sensibility in food and drink may be most easily recognized. Consider the appeal of sweetness. Soft drinks contain so much sugar that, in granular form, it usually fills over half the container. Normal thirst and the appeal of a sweet taste are turned into a commercial drink of high profitability but with unhealthy effects. Moreover, sugar is regularly added to most prepared 
foods, from breakfast cereal ${ }^{19}$ to salad dressing, not to mention being a major ingredient in baked goods and most canned and packaged foods, as well as in fruit juices and other kinds of drinks.

Having a sweet tooth is more than an innocent indulgence; it carries consequences for health. Sugar is associated with what is called the metabolic syndrome: obesity, heart disease, and diabetes. Moreover, sugar is addictive and plays a part in encouraging the consumption of other addictive substances, including the caffeine in 'Coke' and coffee and in a range of alcoholic drinks including wine, liqueur, and mixed drinks. Salt is another food substance where a tasteful and necessary substance is often found to excess in most prepared foods and a 'taste' for salt is encouraged. At the same time, its influence in heightening blood pressure is well-documented.

Other gastronomic examples are plentiful. Consider the high use of fats and oils in deep-fried fast food that leads to obesity and high cholesterol levels. ${ }^{20}$ French fries are a vivid example, where the fat-saturated outer crust often penetrates and displaces any soft potato core. In addition, cream or cheese sauces are ladled over many dishes, preceded by cream soup and accompanied by a lavish supply of rolls and butter, not to mention the rich dessert offerings. Please note that I am not condemning the appeal of such foods but rather the encouragement of patterns of exaggerated taste and over-consumption that underlie their use. Taste is largely formed by learning, and the omnipresence of advertising encourages and underlies the acquisition of such inflated desires. To put it baldly, our very sensibility is being exaggerated in order to encourage profitable consumption.

Smell is another sense modality that has been co-opted. False fragrances are infused into a multitude of products, from hand cream and bar soap to laundry and dish detergents, so that it is difficult to know how anything actually smells. Fragrant overlays suffuse hotel rooms and emanate from pets and people. A principal source of perceptual information has been lost. Still another impingement on sensibility lies in the garish colors used in clothing, home decoration and, of course, in print advertising and on the Internet. Strident colors are so widespread on signs and clothing that subtle and muted colors are not noticed or have simply disappeared from the marketplace altogether.

Musical sound has a place in nearly every culture and it is especially prevalent in modern developed societies. Sound is an elusive phenomenon. While we can usually identify its source, sound spreads broadly and, like perfume, tends to 
envelop us. This is one of the appealing qualities of musical experience, but in some cases this attractive feature is exaggerated so as to become oppressive and inescapable. Extremely high volume is used in some rock concerts to increase the appeal of the music and create a manic, indeed frenetic audience response. Such high volume is intended to impress the audience by its sheer force, and indeed one can literally feel the physical pressure of the sound waves. This presumably attracts a large attendance and makes such entertainment highly profitable. Other consequences may take a little longer to recognize, such as the hearing loss from damage to the tiny hair-like cells in the cochlea of the inner ear that are the auditory nerve receptors.

Even the auditory environment is not safe. Because sound is intangible and invisible, it is easily imposed on others with impunity. Public space has long been taken over by businesses that sell sound in the form of canned music to fill empty sound-space. Commercial sound saturates transitional public places, such as waiting rooms, bars, restaurants, malls, and even the streets. And when canned sound is not present, people cooperate by supplying it through their own headsets. Silence, even relative silence, has become a rarity.

Then there are the means by which sensibility is distorted or drugged. One of the most widespread and insidious practices of cultivating sensory pleasure for profit is, of course, cigarette smoking. Few smokers enjoyed their first cigarette: the taste is unpleasant, the smoke choking, the physical effects nauseating. But the appeal of emulating celebrities, the desire to display sophistication, peer pressure, and the attraction of transgression are powerful incentives. The tobacco industry uses these successfully to create the desire in many people to overcome their initial distaste, gradually leading to an acquired taste and nicotine addiction with its deleterious consequences.

The use of alcohol has become a regular pastime for many people, reinforced in popular culture on TV and in film by romanticizing drinking and appealing to self-indulgence. It is much like the way cigarette smoking was associated with sophistication until its damaging effects on health were shown to be so widespread and costly that legal measures were enacted in some developed countries to prohibit smoking in public places and by the young. Alcohol abuse may be somewhat less visible than smoking, but it is a public health problem of epidemic proportions. At the same time, the production and dissemination of alcohol is a major industry for drugging sensibilities, and its manifold forms, from beer, wine, and iced tea to mixed and straight drinks, is widely encouraged on many social and economic levels. The excessive use of alcohol is a major public health menace that carries high personal and social costs. 
A related instance in which sensibility has been co-opted is pornography. The pornography industry profits enormously from appropriating people's normal erotic sensibility, removing it from feelings of caring and the richness of complex human relationships, narrowing it into pure titillation, and exaggerating it by excess in order to stimulate erotic feelings by focusing on pure sensuality.

It is clear the co-optation of sensibility is a distinctive mode of aesthetic exploitation. Some of its techniques are easily recognized once they have been identified, such as the exaggeration or vulgarizing of sensory stimuli in order to enhance their direct appeal. Other modes of sensory manipulation include the perceptual deceit in falsifying perception through the use of chemical fragrances and flavors that emulate natural ones. Such perceptual deceit is not confined to the food industry but is pervasive in the cleaning and sanitary supplies used in households and public facilities.

But there is yet another form of sensory manipulation that is directly psychological without the intermediary of tempting foods or entertainment. This consists in using sensory stimuli to create low-level anxiety, making people less attentive, less in control, even spaced-out, and so more suggestible and vulnerable. Chimes, bells, canned music, repeated public announcements, sprayed aromas are pervasive in virtually every public place: waiting rooms, lobbies, supermarkets, retail stores.

This promotion of anxiety assumes a particularly insidious form of sensory manipulation when it cultivates the apprehension of violence. Violence is made commonplace through insistent exposure in film, television, computer games, and on the Internet. It is the substance of TV news programs and news channels and a habitual form of mass audience entertainment. Violent behavior is depicted as commonplace and acceptable, and it is put to political use in justifying restrictions and control by exaggerating a sense of alarm in an endless succession of crises beyond immediate circumstances where there may be reasonable danger, crises that range from impending changes in the weather to political confrontations and belligerent actions between ethnic, religious, and national groups. The heightened sensibility of violence pervades public places, leading to often exaggerated security conditions. All this has an underlying aesthetic foundation in creating a permanent sensibility of alarm by cultivating a simmering somatic state of apprehension.

There is a pattern behind these practices that it is important to isolate and identify; indeed, this is the purpose of my discussion. The practice of influencing, 
of deliberately cultivating a distorted sensibility, altering people's taste and responses to an exaggerated or excessive degree without their clear awareness or consent, this is what I am calling the co-optation of sensibility. The ability to experience sensory pleasure is at the center of aesthetic appreciation of the arts, and sensible enjoyment plays a central part in most of the experiences of living. The practices I am identifying appropriate this native ability and exploit it in order to create a market for extreme tastes. Thus the very capacity for perceptual enjoyment is appropriated and shaped mainly for profit or control. To seduce our aesthetic need and capacity by creating a desire for extreme degrees of sensory craving in order to capture a consumer market is, I believe, both aesthetically and morally vicious. ${ }^{21}$ Our very sense of beauty is subverted by exaggeration and excess. This is a pattern of manipulation that pervades industrial-commercial culture and it is promoted for multiple purposes, from creating the market for a fashion and the conformity it encourages, to acquiring the political control such conformity enables.

It might seem that I am condemning all those appealing qualities and things that give pleasure to daily life, but that is not so. The problem, as I see it, is not in liking the taste of sugar, salt, or alcohol, or in seeking erotic pleasure. It lies in the pursuit of profit or control by sensory manipulation to promote excessive indulgence through miseducating our sensibilities regardless of their detrimental effects on health and wellbeing. That is to say, our sensory delight in tastes and flavors, our curiosity and interests, have been deliberately mis-schooled. Sensible pleasures have been exaggerated and encouraged to the point of overindulgence, resulting in higher profits for their producers and woeful consequences to their consumers. Our desires, our judgments of taste, our very sensibility have been co-opted: they have been appropriated and exaggerated and our self-indulgence encouraged in the interests of commercial profit and political control.

It is not my intent here to condemn the profit motive, as such, but rather to expose its causal influence in this practice of aesthetic exploitation by promoting, therefore educating the public to hyper-sensation, so to say. The tastes I have been discussing rest on normal impulses but they are vulnerable to exploitation. To appropriate these desires, to intensify and exaggerate them by encouraging harmful patterns of excessive consumption, is to take advantage of people's vulnerability by exploiting their aesthetic needs. Such practices are unmitigated moral wrongs. 
The insidiousness of sensory co-optation lies in the stealthy insinuation and cultivation of a distorted perceptual sensibility. The analysis I have offered of this phenomenon of mass culture documents the pervasiveness of the aesthetic in daily life and reveals ways in which it has been misused. ${ }^{22}$ Be that as it may, it could be objected that every culture possesses its own complex, pervasive sensibility. We can identify distinctive preferences in culinary taste, characteristic smells, bodily deportment, patterns of physical movement, speech intonation, vocal quality and style, soundscape - the full range of human sensibility - that characterize particular social classes, societies, and historical epochs. Why condemn mass industrial culture for elaborating its own distinctive sensibility?

This objection rests on a true premise: every culture imbues its members with a range of awareness that is indigenous to the human world it elaborates. We do not choose our cultural sensibility any more than we choose our native language, our parentage, or our ethnicity. We may decide, later, to adopt another, but rarely can this be done completely. Vestiges of our natal culture remain - in speech intonation, in choice of colors and style of dress, in posture, in facial expression.

Yet the sensible characteristics I have been identifying here emerge from different origins and motives and implicate a different morality. And they carry clear consequences and invoke a different order of moral judgment. The critique of mass consumer culture I have been elaborating here is not confined to that condition, alone. At the same time, I do not endorse a relativism of cultures. I believe that a cultural order that does not value and respect human life eo ipso but denigrates others who are different in skin color, religion, customs, or language is lower on a scale of civilization than one that respects difference on the basis of a common humanity. A society that benefits from the exploitation of other humans is lower on a scale of civilization than one that respects the varied manifestations of the human condition we all share.

\section{I I}

But let me now consider some of the consequences of aesthetic exploitation through encouraging sensory excess and the co-optation of sensibility. One is the corruption of taste. The rich source of human satisfaction in aesthetic pleasure is distorted by exaggeration, and the distortion becomes habitual. At the least, such excess encourages patterns of over-indulgence that may serve as compensation for the lack of other satisfactions. The yearning for sensory 
excess may also lead to extreme behavior and substance abuse. This is not to say that there is a necessary connection between an exaggerated sensibility and such effects, but rather that the habitual practice of sensory extremes cannot but have harmful consequences.

The effects of these practices have been extensively documented. I noted earlier the health problems caused by sugar addiction and the hearing loss from exposure to very high decibel levels. Indeed, sensory extremes can cause decreased perceptual sensitivity in general, so that we notice only gross stimuli. The quality of human life declines precipitously when whole regions of perceptual experience are distorted, impaired, or inaccessible.

The co-optation of sensibility has wide social and environmental consequences as well as personal ones. Let me offer one compelling illustration: the taste for sugar. The growth of the global market for sugar has been studied extensively and provides a dramatic example of the heinous effects of the extreme demand for sensory satisfaction. The sugar economy began in the fourteenth century and grew rapidly. This encouraged the widespread development of plantation agriculture, a system that displaced indigenous subsistence cultivation, resulting in a drastic decrease in food production for the local economy. At the same time, the need for laborers to work the plantations led to the enslavement and the partial or complete extinction of certain native Caribbean Amerindian groups. ${ }^{23}$ When this source of labor became insufficient, it encouraged the rapid growth of the African slave trade to replace it. ${ }^{24}$ A similar instance of sensory exploitation, in this case centering on public health, can be made for the tobacco economy. The tobacco industry spends billions of dollars a year on advertising, and tobacco use costs billions a year in medical expenses and lost productivity. Indeed, at the present time tobacco use is the second highest cause of death in the world. ${ }^{25}$

Apart from the dramatic, large-scale consequences of sensory co-optation, there are pervasive social effects. Mass culture subjects people to constant ambient sound, to unsolicited visual intrusion, to the oppressive stimuli of the mass media and the pressures of mass population. These intrusions cannot help but produce a condition of sensory excess with the result that we may easily be overcome by perceptual exhaustion and become insensitive, even anaesthetized to sensory stimuli. Because these forces are so widespread and omnipresent, decreased sensibility generally cannot help but produce fundamental changes in the cultural ethos. 
The co-optation of sensibility carries moral implications, as well. The appropriation of sensibility for profit, for control, or for other external motives violates fundamental ethical norms. Most forceful is the deeply-rooted value in the sanctity of human life: the belief that life is the ultimate good and must be honored above all else. From the teachings in the Judeo-Christian traditions that, in the golden rule, oblige us to recognize our common humanity, to Kant's categorical imperative ${ }^{26}$ that enjoins us against using other humans as means only, the Western ethical tradition subscribes to norms that condemn exploitative practices, including those I have been identifying here.

These practices have philosophical implications as well as social and moral ones. Hume's standard of taste has been violated..$^{27}$ The expert critic has been replaced by the authority of popular taste, taste that has been perceptually exaggerated in the service of consumption to the detriment of public health and the environment. The very capability for sensory perception has been damaged and the capacity for fine, nuanced aesthetic experience subverted, affecting not only perception in the arts but our sensory experience in general. Corrupted by exaggeration and distorted beyond recognition, the capability of developing discerning taste has been miseducated in the service of excessive consumption: expert taste has become popular distaste. ${ }^{28}$ As with other normative judgments, aesthetic judgment is capable of degrees of negativity, but the moral issue is always negative because taste, that is, aesthetic perception, has been manipulated for external ends.

The practices I have been describing are endemic in global industrialcommercial culture, where the miseducation of natural sensibility is promoted by a huge advertising industry. ${ }^{29}$ There are undoubtedly regional and national variations but the pattern is everywhere the same. Since these personal excesses feel 'normal' to unreflective, miseducated consumers, their aesthetic harm, is subtle yet sinister. The result of such widespread and comprehensive co-optation of our perceptual modalities is that our very sensibility has been appropriated, our aesthetic orientation in the world distorted, and our behavior made self-injurious. For these reasons the co-optation of sensibility is the more insidious because it distorts the very capacity for sensible perception. In subverting the beauty in experiencing aesthetic value by a discerning sensibility, it diminishes the richness of life. 
The aesthetic analysis I have pursued in this essay is based on the observation of mass consumer culture in the United States. I expect that, with the rapid spread of a global economy, similar techniques of sensory co-optation are prevalent in other countries in the developed world, and perhaps even more so in third-world regions, where consumers are less experienced and more vulnerable to the marketing strategy of sensory co-optation.

This paper complements the important work now being done on the aesthetic characteristics of everyday life. Investigating the aesthetics of ordinary experience exposes domains of value hidden in common objects and situations. But there are other functions of everyday aesthetics besides uncovering new regions of positive aesthetic value. Exploring these areas reveals manifestations of aesthetic value that do not enhance the quality of experience but rather distort and diminish it in subtle as well as overt ways through the multiple forms and kinds of negative value. ${ }^{30}$

This paper moves beyond the manifestly negative, exposing a mode of aesthetic negation that burrows beneath the surface of sensible experience and contaminates it by a practice I identify as the co-optation of sensibility. Such an analysis opens the way to further research in the psychology of perception, in social psychology and sociology, in business ethics and other related fields. Indeed, it shows how the aesthetic analysis of ordinary life has wide-reaching social and political implications, and an ethical significance that extends even farther. This suggests another role for aesthetics, a critical one: aesthetics as a tool of social analysis and political criticism. It remains to be seen where it will lead. ${ }^{31}$ 
NOTES

1

2

3

Katya Mandoki, Everyday Aesthetics: Prosaics, the Play of Culture, and Social Identities (Hampshire: Ashgate Publishing Limited, 2007).

Sir Francis Bacon, Novum Organum, by Lord Bacon, ed. by Joseph Devey, M.A. (New York: P.F. Collier, 1902).

Spinoza, The Ethics, Part IV, Prop. LXVI, Note. The Chief Works of Benedict de Spinoza, trans. R.H.M. Elwes (New York: Dover, 1951), Vol. II, p. 232

Spinoza, The Ethics, Part IV, Prop. LXVI, Note. The Chief Works of Benedict de Spinoza, trans. R.H.M. Elwes (New York: Dover, 1951), Vol. II, p. 232.

N.B. I have slightly modernized the translation.

Arnold Berleant, Sensibility and Sense: The Aesthetic Transformation of the Human World (Charlottesville: Imprint Academic, 2010), p. 156.

Yuriko Saito, “The Aesthetics of Unscenic Nature," JAAC (Vol. 56, No. 2, Spring 1998), 101-111. Thomas Leddy, The Extraordinary in the Ordinary: The Aesthetics of Everyday Life (Peterborough, Ont: Broadview, 2012).

See Arnold Berleant, Sensibility and Sense, Ch. Nine, "The Negative Aesthetics of Everyday Life" and Ch. Ten, "Art, Terrorism, and the Negative Sublime."

See Crispin Sartwell, Political Aesthetics (Ithaca: Cornell University Press, 2010); Davide Panagia, The Political Life of Sensation (Duke University Press, 2009); Arnold Berleant, Sensibility and Sense, Part Three: Social Aesthetics; Arnold Berleant, Aesthetics beyond the Arts (Ashgate, 2012), ch.16, "The Aesthetic Politics of Environment."

Pauliina Rautio, "On Hanging Laundry: The Place of Beauty in Managing Everyday Life," Contemporary Aesthetics 7 (2009).

Yuriko Saito, "Future Directions for Environmental Aesthetics," Environmental Aesthetics: Crossing Divides and Breaking Ground, ed. Martin Drenthen and Jozef Keulartz (New York: Fordham University Press, 2014), p. 26.

The literature on everyday aesthetics is already substantial and growing. While it is a recent trend, it has long been recognized. See, for example, John Dewey, Art as Experience (New York: Minton, Balch, and Co., 1934) and Melvin Rader and Bertram Jessup, Art and Human Values (Englewood Cliffs,: Prentice-Hall, 1976), especially chapter 5. Important contributions to the resurgence of interest in everyday aesthetics are Aesthetics of Everyday Life, ed. Andrew Light and Jonathan M. Smith (New York: Columbia University Press, 2005); Katya Mandoki, Everyday Aesthetics: Prosaics, the Play of Culture and Social Identities (Aldershot: Ashgate, 2007); Yuriko Saito, Everyday Aesthetics (Oxford: Oxford University Press, 2007); Thomas Leddy, The Extraordinary in the Ordinary: The Aesthetics of Everyday Life (Peterborough, Ont: Broadview, 2012); Aesthetics of Everyday Life, East and West, ed. Liu Yuedi and Curtis L. Carter (Newcastle upon Tyne: Cambridge Scholars Publ., 2014).

Cf. A. Berleant, "What Is Aesthetic Engagement?", Contemporary Aesthetics, Vol. 11 (2013), http://www.contempaesthetics.org/newvolume/pages/article.php?articleID=684 .

Small efforts at mitigation do not alter the basic pattern.

This expectation and practice supports the credit card industry.

See the Journal of Business Ethics (www.springer.com/...ethics/journal/105...).

Melvin Rader and Bertram Jessup, Aesthetics and Human Values.

What I mean by 'co-optation' is neither an external force working on sensibility nor an internal impulse but a cultural phenomenon whereby sensitivities and perceptual desires (appetites) grounded in the human organism are quietly appropriated by social-cultural mechanisms, such as (subliminal) advertising, mis-education, influences on style and crowd behavior, etc. for purposes not consciously chosen by the percipient. Those purposes may be political (in a broad, inclusive sense), economic or, more generally, social. should make many health-conscious consumers happy: 'no high fructose corn syrup.' The only problem: it's not true. These General Mills products all contain a super-concentrated sweetener 
that is made from high fructose corn syrup, and within the Big Ag industry is literally called "HFCS-90" or high fructose corn syrup-90. But then the Corn Refiners Association changed the name to "fructose." And now General Mills is not only disingenuously hiding their corn syrup behind this innocuous alias -- the company is bragging that it's products don't contain any! The "fructose" label is especially nefarious, since fructose is a naturally occurring fruit sugar, and HFCS-90 is a highly concentrated, highly processed product that is molecularly different from the fructose you would eat in your apple. The corn industry waves away HFCS-90 as a minor ingredient, stating "HFCS-90, is sometimes used in natural and 'light' foods, where very little is needed to provide sweetness." But that's clearly not the case. According to the label, there is actually more HFCS-90 in Cinnamon Chex than there is actual cinnamon!" "High-fructose corn syrup more toxic than sugar, study finds," Oregonian, 1/5/15; "General Mills Will Stop Marketing Synthetic Products As "Natural' To Make Them Appear Healthier," Credo petition, 20 Jan 15. act@credoaction.com. Accessed 11/19/14.

The "Big Mac," for example, is a hamburger consisting of two high-fat patties topped by a slice of American cheese, with dressing, lettuce, pickles, and onions on a sesame bun, all of which contains as much or more fat than protein. In the U.S., A Big Mac contains 29 grams of fat to 25 grams of protein, with similar proportions in the many other countries where Macdonald's restaurants are found. Japan has the highest proportion of fat: 30.5 grams to 25.5 grams of protein. See the article and references on "Big Mac" in Wikipedia (accessed 11 Nov 2014).

Cultivating an exaggerated sensibility in the art market by paintings of greater than life size and colorful excess by artists such as Roy Lichtenstein and Chuck Close might be said to symbolize as well as represent this practice. I do not ascribe to such artists the devious manipulation of the advertising industry but rather cite them as perhaps succumbing to its influence.

A revealing account of the practice of shaping sensibility for the purpose of promoting profit is what is known as the "experience economy," a concept introduced by Joseph Pine II and James Gilmore ("Welcome to the Experience Economy," Harvard Business Review, July-August, 1998, 97-105). I thank Yuriko Saito for this reference. As she describes it, "this economy is premised on the belief that it is insufficient for today's business to merely sell goods and services. They must also sell experiences associated with the environment surrounding the sale of their goods and services. The branding of Apple distinguishes not only the Apple products but also the whole atmosphere of Apple Store. The same applies to phenomena such as Niketown, Hard Rock Café, and Starbucks. Sometimes referred to as 'shoppertainment' or 'entertailing,'(99), everything in the store is scripted and designed to promote 'customer participation,' 'environmental relationship,' and 'a well-defined theme' through 'engage(ing) all five senses' (102-104). For example, 'the mist at the Rainforest Café appeals serially to all five senses. It is first apparent as a sound: Ssssss-zzz. Then you see the mist rising from the rocks and feel it soft and cool against your skin. Finally, you smell its tropical essence, and you taste (or imagine that you do) its freshness'(104). Or, recent proliferation of a bookstore combined with café is based upon the discovery that 'the aroma and taste of coffee go well with a freshly cracked book,' while one chain of laundromat went bust 'attempting to combine a bar and a coin-operated laundromat' because it was found that 'the smells of phosphates and hops, apparently, aren't mutually complementary'(105)." Yuriko Saito,, unpublished comments, American Society for Aesthetics annual meeting, San Antonio, TX, 31 Oct. 2014.

Arawaks and Caribs, among others. in Modern History (Boston: Beacon Press, 1985; Penguin, 1986). Another one can be found at http://www.learner.org/courses/worldhistory/support/reading_14_1.pdf, taken from Bridging World History, The Annenberg Foundation copyright (C) 2004. elsewhere. 
David Hume, “Of the Standard of Taste," in Essays: Moral. Political, and Literary, ed. Eugene F. Miller (Indianapolis: Liberty Fund, 1985). Available online at www.csulb.edu/ jvancamp/361r15. html. This essay is widely anthologized. Witness the common condemnation of cultivated taste by calling it "elitist." My argument in this essay rests on an analysis of practices endemic in the United States. I suspect that they are commonly found pari passu throughout the developed world wherever corporate culture has acquired the power to form and direct the sensibilities of the mass consumer.

This essay deliberately does not consider the overt manipulation of consumers by all the techniques with which the advertising industry influences behavior. Many of these are not concealed as are the practices described in this essay but, like them, may be considered instances of negative aesthetic value. See my discussion of negative aesthetics in Sensibility and Sense: The Aesthetic Transformation of the Human World (Exeter, UK: Imprint Academic, 2010), Chapter Nine: The Negative Aesthetics of Everyday Life. My concern in the present discussion has been with the negative aesthetic of a subtle but all the more insidious influence on sensibility.

Spinoza may again be prescient: “...[A]11 those things which bring us pleasure are good. But seeing that things do not work with the object of giving us pleasure, and that their power of action is not tempered to suit our advantage, and, lastly, that pleasure is generally referred to one part of the body more than to the other parts; therefore most emotions of pleasure (unless reason and watchfulness be at hand), and consequently the desires arising therefrom, may become excessive. Moreover we may add that emotion leads us to pay most regard to what is agreeable in the present, nor can we estimate what is future with emotions equally vivid." The Ethics, Part IV, Prop. XXX, p. 242 .

"We may thus readily conceive the power which clear and distinct knowledge, and especially that ... founded on the actual knowledge of God [nature] possesses over the emotions: if it does not absolutely destroy them, in so far as they are passions...; at any rate, it causes them to occupy a very small part of the mind." The Ethics, Part V, Prop. XX, Note, V, p. 256.

I am grateful for suggestions and information from Riva Berleant-Schiller, Aleš Erjavec, Kevin Melchionne, and Larry Shiner. 
Berleant, Arnold. Sensibility and Sense: the Aesthetic Transformation of the Human World.

Charlottesville: Imprint Academic, 2010.

Berleant, Arnold. Aesthetics beyond the Arts. Ashgate, 2012.

Berleant, Arnold. "What Is Aesthetic Engagement?" In Contemporary Aesthetics, 11 2013: accessed July 21, 2015. Url: http://www.contempaesthetics.org/newvolume/pages/article. php?articleID $=684$

Dewey, John. Art as Experience. New York: Minton, Balch, and Co., 1934.

Elwes, R.H.M., trans. The Ethics, Part IV, Prop. LXVI, Note. The Chief Works of Benedict de Spinoza. New York: Dover, 1951.

Hume, David. "Of the Standard of Taste," in Essays: Moral, Political, and Literary, edited by E.F. Miller. Indianapolis: Liberty Fund, 1985.

Kant, Immanuel. Fundamental Principles of the Metaphysics of Morals. Translated by Thomas K. Abbott. (1785)

Leddy, Thomas. The Extraordinary in the Ordinary: the Aesthetics of Everyday Life. Peterborough, Ont: Broadview, 2012.

Light, Andrew and Smith, Jonathan M., editors, Aesthetics of Everyday Life. New York: Columbia University Press, 2005.

Mandoki, Katya. Everyday Aesthetics: Prosaics, the Play of Culture and Social Identities. Aldershot: Ashgate, 2007.

Mintz, Sidney W. Sweetness and Power: the Place of Sugar in Modern History. Boston: Beacon Press; Penguin edition, 1986.

Panagia, Davide. The Political Life of Sensation. Duke University Press, 2009.

Pine, Joseph, II, and Gilmore, James. "Welcome to the Experience Economy," in Harvard Business Review. July- August, 1998.

Rader, Melvin and Jessup, Bertram. Art and Human Values. Englewood Cliffs: Prentice-Hall, 1976.

Rautio, Pauliina. (2009). "On Hanging Laundry: the Place of Beauty in Managing Everyday Life.” Contemporary Aesthetics, 7: accessed July 21, 2014. Url: http://www. contempaesthetics.org/newvolume/pages/article.php?articleID=535.

Saito, Yuriko. Everyday Aesthetics. Oxford: Oxford University Press, 2007.

Saito, Yuriko. "The Aesthetics of Unscenic Nature." JAAC, 56, 2. Spring, 1998.

Saito, Yuriko. "Future Directions for Environmental Aesthetics." In Environmental Aesthetics: Crossing Divides and Breaking Ground, edited by Martinus Drenthen and Joseph Keulartz. New York: Fordham University Press, 2014.

Saito, Yuriko. Unpublished Comments. American Society for Aesthetics annual meeting. San Antonio, TX: October 31, 2014.

Sartwell, Crispin. Political Aesthetics. Ithaca: Cornell University Press, 2010.

Yuedi, Liu and Carter, Clarence, editors Aesthetics of Everyday Life, East and West. Newcastle upon Tyne: Cambridge Scholars Publ., 2014. 


\title{
STATUS ESTETIKE DANAS
}

\begin{abstract}
Aleš Erjavec
U svom radu ću ispitati neke od prekretnica u novijoj istoriji estetike. Tvrdim da su nedavni događaji u estetici ne samo proširili njenu paletu interesa i učinili je savremenijom nasuprot konkurentnoj umetnosti, već su takođe uveli estetiku u oblasti koje prethodno nisu bile njene. U tom smislu, vidim Žaka Ransijera kao glavnu figuru, čiji nedavni spisi nude mogući pokušaj romana - mada takođe rizično. Osim toga, ja ću ispitati neke druge - divergentne, ali i veoma produktivne - estetske teorije poslednjih decenija.
\end{abstract}

KLJUČNE REČI: ESTETIKA, ISTORIJA, ŽAK RANSIJER, UMETNOST, PREKRETNICE

\section{KOOPTACIJA SENZIBILITETA I SUBVERZIJE LEPOTE \\ Arnold Berlant}

Estetska analiza svakodnevnog života je razvila važan opus čiji značaj prevazilazi akademski. Zbog svoje rasprostranjenosti u iskustvu, estetski senzibilitet ima mnogo manifestacija, kako otvorenih tako i skrivenih. Ovaj rad ispituje neke u velikoj meri skrivene načine na koje su ukus i estetski sud, koji se manifestuju u dojmu, suptilno prisvojeni i eksploatisani. Ja identifikujem i opisujem takve postupke kao kooptaciju (ili prisvajanje) estetskog senzibiliteta, što je fenomen koji ima posledice štetne po zdravlje, društvo, i životnu sredinu. Ovi postupci su oblik negativne estetike koja narušava i manipuliše razumnim iskustvom u interesu masovnog marketinga i političke kontrole. Takve prakse imaju veliki etički značaj i nose društvene i političke implikacije koje ukazuju drugu ulogu estetike, onu kritičku: estetika kao instrument emancipacije u društvenim analizama i političkom kriticizmu.

KLJUČNE REČI: ESTETSKI SENZIBILITET, KOOPTACIJA, NEADEKVATNO OBRAZOVANJE, DOBIT, UKUS

\section{KAKO BRANITI ESTETIKU?}

\section{Lev Kreft}

Milan Damnjanović (1924-1994) objavio je svoj estetski opus u kontekstu (Jugoslovenskog) marksističkog "prevazilaženja" (Aufhebung) estetike i estetske samokritike izražene kao "kriza estetike". Da bi se suprotstavio obema ovim kritičnim pozicijama i u isto vreme reformisao sposobnost estetike da tretira sve estetske fenomene, ali i dalje zadržao umetnost u posebnom fokusu, on je uveo problem neposrednosti doživljaja sveta od strane čoveka. U svom članku "Problem neposrednosti i posredovanja u Marksovoj misli" (1970) Damnjanović je želeo da pokaže primat estetske dimenzije u neposrednosti i neposredno posredovanje/razmišljanje koje može da podrži legitimno pravo filozofije da je organizuje kao otvoreni sistem, i solidnost estetike kao disciplinu takvog sistema. Da bi postigao ovaj cilj, predstavio je isprepletenu argumentaciju koja kombinuje njegovo tumačenje Marksove filozofije rada iz pariskih rukopisa i Kapitala sa Plesnerovom esteziologijom i Valerijevom "esthésique".

Preispitivanje Damnjanovićeve odbrane Celine, filozofske sistematičnosti, i autonomnog položaja estetike kao discipline je prilika da se utvrdi da li je ukazao na pravi smer, bilo uzimajući Plesnera i Valerija kao podršku, ili, uzimajući osnovni filozofski problem neposrednosti / posredovanja kao kamen temeljac statusa estetike. 